\title{
PENGARUH PEMBERIAN EKSTRAK AIR PANAS Spirulina platensis PADA PAKAN TERHADAP KELANGSUNGAN HIDUP DAN TOTAL HEMOSIT UDANG VANAME SETELAH DIINFEKSI DENGAN Vibrio harveyi
}

\section{The Effect of Dietary Hot Water Extract of Spirulina Platensis on Survival Rate and Total Haemocyte Count of White Leg Shrimp After Infection With Vibrio Harveyi}

\author{
Ayu Puspitarani ${ }^{1}$, Woro Hastuti Satyantini ${ }^{2}$ dan Rahayu Kusdarwati ${ }^{2}$. \\ ${ }^{1}$ Program Studi Budidaya Perairan, Fakultas Perikanan dan Kelautan, Universitas Airlangga, Surabaya \\ ${ }^{2}$ Departemen Manajemen Kesehatan Ikan dan Budidaya Perairan, Fakultas Perikanan dan Kelautan, Universitas \\ Airlangga, Surabaya \\ *ayu-p-10@fpk.unair.ac.id
}

\begin{abstract}
Abstrak
Udang vaname (Litopenaeus vannamei) merupakan suatu komoditas perikanan yang memiliki nilai ekonomi penting. Produksi udang vaname (Litopenaeus vannamei) mengalami kendala akibat adanya wabah penyakit. Salah satunya adalah akibat serangan bakteri Vibrio harveyi. Bakteri ini menyebabkan mortalitastinggi. Penanggulanganya umumnya menggunakan antibiotik namun berdampak pada munculnya resistensi bakteri dan residu pada udang. Aplikasi penggunaan bahan alami sebagai imunostimulan seperti Spirulina platensis dalam bentuk ekstrak air panas diketahui memiliki efek stimulator sehingga dapat meningkatkan respon imun pada udang vaname (Litopenaeus vannamei). Respon imun ini diperlihatkan dengan meningkatnya jumlah total hemosit yang berpengaruh langsung dengan nilai kelangsungan hidup.

Penelitian ini bertujuan untuk mengetahui pengaruhpemberian ekstrak air panas Spirulina platensis pada pakan terhadap total hemosit (Total Haemocyte Count) dan nilai kelangsungan hidup udang vaname setelah diuji tantang dengan bakteri Vibrio harveyi. Metode penelitian yang digunakan adalah eksperimental menggunakan metode Rancangan Acak Lengkap (RAL) dengan 5 perlakuan $(0 \mathrm{mg} / \mathrm{kg}, 200 \mathrm{mg} / \mathrm{kg}, 400 \mathrm{mg} / \mathrm{kg}$, $600 \mathrm{mg} / \mathrm{kg}$, dan $800 \mathrm{mg} / \mathrm{kg}$ ) dan 4 kali ulangan. Udang vaname diberikan pakan dengan kandungan ekstrak air panas Spirulina platensis selama 14 hari kemudian pada hari ke-15 udang diuji tantang dengan cara diinjeksi dengan bakteri Vibrio harveyi dosis $10^{6} \mathrm{CFU} / \mathrm{ml}$ pada bagian segmen abdominal. Pengamatan terhadap jumlah total hemosit (Total Haemocyte Count) yaitu pada hari ke-0, ke-14, ke-16 dan ke-26. Pengamatan terhadap nilai SR (Survival Rate) dilakukan selama sepuluh hari pasca udang diinfeksi.

Hasil penelitian menunjukkan adanya peningkatan jumlah total hemosit pada udang vaname (Litopenaeus vannamei) akibat pemberian ekstrak air panas Spirulina platensis dibandingkan dengan perlakuan kontrol (tanpa pemberian ekstrak air panas Spirulina platensis). Pemberian ekstrak air panas Spirulina platensis juga efektif meningkatkan nilai kelangsungan hidup (Survival rate) udang vaname pasca infeksi dengan bakteri Vibrio harveyi dengan perlakuan terbaik pada dosis sebesar $800 \mathrm{mg} / \mathrm{kg}$ pakan.
\end{abstract}

Kata kunci : Spirulina platensis, Ekstrak Air Panas, Total Hemosit, Kelangsungan Hidup

Abstract

White leg shrimp (Litopenaeus vannamei) is the one commodity that has an important economic value. Production of white leg shrimp (Litopenaeus vannamei) had many problems due to disease outbreaks. One is causes from Vibrio harveyi bacteria. This bacteria causes high mortality. To overcome this problem, commonly used antibiotics but the impact of is on the emergence of bacterial resistance and residues in shrimp. Applications use of natural materials as immunostimulant Spirulina platensis in the form of hot water extracts known to have a stimulatory effect to enhance the immune response in white leg shrimp (Litopenaeus vannamei). This immune response is shown by the increasing number of total haemocytes count that directly affect the value of survival rate.

This study aimed to determine the effect of hot water extract of Spirulina platensis on the feed to the total haemocytes (Total Haemocyte Count) and survival ratewhite leg shrimp after challenged tested with Vibrio harveyibacteria. The method used is an experimental method completely randomized design (CRD) with 5 treatments $(0 \mathrm{mg} / \mathrm{kg}, 200 \mathrm{mg} / \mathrm{kg}, 400 \mathrm{mg} / \mathrm{kg}, 600 \mathrm{mg} / \mathrm{kg}$, and $800 \mathrm{mg} / \mathrm{kg})$ and 4 replications. White leg shrimp(Litopenaeus vannamei) given feed containing hot water extract of Spirulina platensis for 14 days later on the 15 th day of shrimp challenged tested with Vibrio harveyi were injected with a dose of $10^{6}$ cell $/ \mathrm{ml}$ in the 
abdominal segment. Observation of the total number of hemocytes (Total Haemocyte Count) is on days 0,14 th, 16th and 26th. Observation of the value of survival rate was did for ten days after the shrimp infected.

The results showed an increase in the total number of haemocytes in white leg shrimp (Litopenaeus vannamei) due to the provision of hot water extract of Spirulina platensis compared with control (without hot water extract of Spirulina platensis). Hot water extract of Spirulina platensis also effectively improve the survival rate white leg shrimp post-infection with Vibrio harveyi bacteria with the best treatment at a dose of $800 \mathrm{mg} / \mathrm{kg}$ diet.

Keywords: Spirulina platensis, Hot Water Extract, Total Haemocytes, Survival Rate

\section{PENDAHULUAN}

Udang vaname (Litopenaeus vannamei) merupakan suatu komoditas perikanan yang bernilai ekonomi penting. $\mathrm{Na}-$ mun dalam budidayanya sering mengalami kendala seperti adanya serangan penyakit akibat bakteri, virus atau parasit. Salah satu penyakit yang menyerang udang yaitu penyakit vibriosis yang disebabkan oleh beberapa bakteri Vibrio sp. Spesies Vibrio yang sering menyerang udang vaname (Litopenaeus vannamei) adalah Vibrio harveyi dan Vibrio alginolyticus (Tayaget al., 2010). Selama ini penanggulangan penyakit udang bercahaya yang disebabkan oleh bakteri Vibrio harveyi umumnya menggunakan antibiotik. Penggunaan antibiotik sudah dibatasi karena menyebabkan bakteri menjadi resisten serta menimbulkan residu pada udang (Widagdo, 2011).

Salah satu upaya pencegahannya dapat dilakukan dengan menggunakan imunostimulan. Spirulina platensis termasuk cyanobacterium yang sering digunakan sebagai bahan pengkayaan pakan alami karena memiliki bermacam-macam nutrisi (Ibrahem and Ibrahim,2014). Polisakarida termasuk faktor yang berpengaruh dalam sistem imun dan terdapat dalam dinding sel Spirulina platensis. Spirulina platensis juga memiliki kandungan fikosianin yang diketahui memiliki efek antioksidan, anti-inflamasi, dan heaptoprotective yang dapat menstimulasi produksi sel darah putih (Desaiand Sivakami, 2004). Kandungan lipopolisakarida dalam Spirulina platensis juga diketahui menunjukkan aktivitas immunostimulan yang ditunjukkan dengan adanya stimulasi produksi antibodi makro dan mikroglobulin dan kenaikan makrofag secara signifikan pada kelinci (Besednova, 1979 dalam Winarni,2014).

Berdasarkan hal tersebut, dilakukan penelitian untuk mengetahui pengaruh pemberian ekstrak air panas Spirulina platensis terhadap kelangsungan hidup dan total hemosit udang vaname (Litopenaeus vannamei) setelah diinfeksi dengan bakteri Vibrio harveyi.

\section{METODOLOGI \\ Waktu dan Tempat}

Penelitian dilaksanakan di Laboratorium Pendidikan Fakultas Perikanan dan Kelautan Universitas Airlangga, Fakultas Farmasi Universitas Airlangga dan Balai Karantina Ikan Kelas 1 Juanda pada bulan September 2014-November 2014.

\section{Materi Penelitian}

Peralatan Penelitian

Alat penelitian yang digunakan antara lain akuarium ukuran 60x30x30 cm, aerator, selang aerator, timbangan digital, mikroskop, $\mathrm{pH}$ meter, DO meter, refraktometer, thermometer, ammonia test kit, pipet, syringe, haemocytometer, autoclave, oven, freeze dryer.

\section{Bahan Penelitian}

Bahan yang dibutuhkan antara lain udang vaname (Litopenaeus vannamei) ukuran $\pm 12,4$ gram yang didapat dari BBPBAP (Balai Besar Pengembangan Budidaya Air Payau) Situbondo, bubuk Spirulina platensis dan isolat bakteri Vibrio harveyi yang didapat dari BBPBAP Jepara, pakan udang komersil, akuades, air laut dan khlorin. 


\section{Metode Penelitian}

Penelitian ini bersifat eksperimental dengan menggunakan metode RAL (Rancangan Acak Lengkap) yang terdiri dari 5 perlakuan $(0 \mathrm{mg} / \mathrm{kg}, 200 \mathrm{mg} / \mathrm{kg}, 400$ $\mathrm{mg} / \mathrm{kg}, 600 \mathrm{mg} / \mathrm{kg}$, dan $800 \mathrm{mg} / \mathrm{kg}$ ) dan 4 kali ulangan. Perlakuan pada penelitian ini adalah sebagai berikut: Perlakuan A (Kontrol): ekstrak $S$. platensis $0 \mathrm{mg} / \mathrm{kg}$ pakan. B: ekstrak S. platensis $200 \mathrm{mg} / \mathrm{kg}$ pakan. C: ekstrak S. platensis $400 \mathrm{mg} / \mathrm{kg}$ pakan, D: ekstrak S. platensis $600 \mathrm{mg} / \mathrm{kg}$ pakan E: ekstrak S. platensis $800 \mathrm{mg} / \mathrm{kg}$ pakan.

\section{Prosedur Kerja Hewan Uji}

Udang vaname (Litopenaeus vannamei) dengan berat $\pm 12,4$ gram sebelum diberikan perlakuan diaklimatisasi selama kurang lebih dua minggu di dalam akuarium berukuran $60 \times 30 \times 30 \mathrm{~cm}$ yang dilengkapi aerator sebagai sumber oksigen. Diberikan air dengan volume \pm 50 liter dengan kepadatan 15 ekor udang vaname per akuarium.

\section{Pembuatan ekstraksi Spirulina platensis}

Sebanyak 30 gram tepung Spirulina platensis dimasukkan ke dalam gelas beker kemudikan ditambahkan air panas dengan suhu $\pm 100{ }^{0} \mathrm{C}$ hingga volume 300 $\mathrm{ml}$ dan dibiarkan selama 1 jam kemudian disentrifuse dengan kecepatan $3000 \mathrm{rpm}$ selama 30 menit untuk memisahkan antara residu dan supernatan (Hayashi et al., 2006). Dalam hal ini, supenatan digunakan sebagai bahan penelitian. Supernatan dapat dikering bekukan dengan metode freeze drying.

\section{Persiapan Pakan}

Pakan komersil dengan kandungan protein sebesar $35 \%$ digiling selanjutnya ditambahkan ekstrak air panas Spirulina platensis sesuai dosis perlakuan dan CMC (Carboxymethyl Cellulose) sebagai perekat. Campuran pakan diaduk secara homogen kemudian dicetak dengan alat pembuat pelet dan dikeringkan pada suhu $\pm 40^{\circ} \mathrm{C}$. Pemberian pakan dilakukan sebanyak tiga kali sehari yaitu pada pukul 09.00, pukul 13.00 dan pada pukul 17.00. Pakan yang diberikan sejumlah $3 \%$ dari biomassa udang.

\section{Uji tantang}

Udang vaname yang telah diberi ekstrak Spirulina platensis selama 14 hari kemudian diuji tantang dengan menggunakan bakteri Vibrio harveyi. Sebelum diuji tantang udang vaname dipindahkan terlebih dahulu ke dalam akuarium dengan kepadatan 10 ekor/akuarium. Untuk uji tantang, udang diinjeksi dengan $0,1 \mathrm{ml}$ suspensi bakteri Vibrio harveyi sebesar $10^{6} \mathrm{sel} / \mathrm{ml}$ yang diinjeksi pada bagian segmen abdomen kedua, setelah udang diinjeksi, kemudian dipindahkan dalam akuarium yang diisi air laut steril (Huang, 2013). Terdapat 6 macam perlakuan pada proses uji tantang. Kontrol negatif : Pemberian ekstrak $S$. platensis $0 \mathrm{mg} / \mathrm{kg}$ pakan dan diinjeksi dengan PBS (Phosphate Buffer Saline), kontrol positif : ekstrak $S$. platensis $0 \mathrm{mg} / \mathrm{kg}$ pakan + infeksi Vibrio harveyi. Ekstrak S. platensis $200 \mathrm{mg} / \mathrm{kg}$ pakan + infeksi Vibrio harveyi. Ekstrak $S$. platensis $400 \mathrm{mg} / \mathrm{kg}$ pakan + infeksi Vibrio harveyi. Ekstrak S. platensis 600 $\mathrm{mg} / \mathrm{kg}$ pakan + infeksi Vibrio harveyi. Ekstrak S. platensis $800 \mathrm{mg} / \mathrm{kg}$ pakan + infeksi Vibrio harveyi.

\section{Persiapan Biakan Bakteri Vibrio Harveyi}

Sebelum diuji tantang, bakteri Vibrio harveyi dipasase (diganaskan) terlebih dahulu dengan cara menginfeksi udang yang sehat dengan bakteri Vibro harveyi. Vibrio harveyi kemudian diisolasi dari kulit yang terluka, hati, ginjal dan limpa (Hashem and Barbary, 2013). Bakteri kemudian diinokulasikan pada media TSA (Tryptic Soya Agar) selama 24 jam pada suhu $30^{\circ}$ C. Koloni bakteri Vibrio harveyi yang tumbuh diambil untuk kemudian diinokulasikan kembali pada media TCBS (Thiosulfate Citrate Bile Salt Sucrose) kemudian isolat disimpan pada suhu $30^{\circ} \mathrm{C}$ selama 24 jam selanjutnya di- 
identifikasi untuk mengetahui apakah spesies yang menyerang udang vaname disebabkan oleh bakteri Vibrio harveyi atau tidak.

\section{Kultur Bakteri Vibrio harveyi}

Isolat bakteri Vibrio harveyi yang telah berhasil diidentifikasi kemudian dikultur pada media TSB (Tryptic Soy Broth) selama 24 jam dan disimpan pada suhu $30^{\circ} \mathrm{C}$. Bakteri yang tumbuh kemudian disentrifuse untuk memisahkan antara bakteri dan supernatan, selanjutnya ditambahkan larutan PBS (Phosphat Buffer Saline) sebanyak $10 \mathrm{ml}$ kemudian bakteri dikocok hingga homogen kemudian diamati secara visual dan dibandingkan dengan larutan Mc Farland pada tabung nomor 6 yaitu pada konsentrasi $10^{6} \mathrm{sel} / \mathrm{ml}$.

\section{Parameter Penelitian Parameter utama}

Menurut Ridlo dan Pramesti (2009) pengambilan hemolim udang dilakukan pada pangkal pleopod pada segmen abdominal dekat lubang genital dengan menggunakan syringe $1 \mathrm{ml}$ yang telah dibasahi dengan larutan antikoagulan (Ridlo dan Pramesti, 2009). Antikoagulan yang digunakan merupakan campuran antara komposisi EDTA 0,37 gr, Trisodium sitrat 0,8 gr, Sodium chloride 1,98 gr.

Hemolim diambil pada awal penelitian (hari ke-0), setelah pemberian ekstrak air panas Spirulina platensis (hari ke14), hari pertama setelah udang vaname diinfeksi dengan bakteri Vibrio harveyi (hari-ke 16) dan pada akhir penelitian (10 hari setelah diinfeksi dengan bakteri Vibrio harveyi).

Menurut prosedur Blaxhall and Daishley (1973) yang dimodifikasi oleh Syahilatua (2009), pada perhitungan hemosit udang dilakukan dengan cara meneteskan hemolim ke dalam haemositometer dan dihitung jumlah selnya per $\mathrm{ml}$ di bawah mikroskop cahaya dengan pem- besaran 40 kali dan dihitung dengan menggunakan rumus:

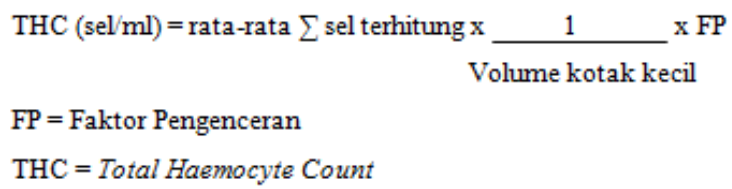

\section{Kelangsungan Hidup (Survival rate)}

Pengamatan terhadap kelangsungan hidup (Survival rate) udang vaname dimulai setelah udang diinfeksi dengan bakteri Vibrio harveyiyaitu pada hari ke-16 hingga hari ke-26.Menurut Effendi (1997) dalam Tampanggalo dkk. (2012) kelangsungan hidup udang vaname (Litopenaeus vannamei) dapat dihitung menggunakan rumus :

$$
\mathrm{SR}=\frac{\mathrm{Nt}}{\mathrm{No}} \times 100 \%
$$

Keterangan:

$\mathrm{SR}=$ Survival Rate (tingkat kelangsungan hidup)

$\mathrm{Nt}=$ Jumlah udang yang hidup pada akhir penelitian

No $=$ Jumlah udang yang ditebar pada awal penelitian

\section{Parameter penunjang}

Parameter penunjang penelitian ini adalah data kualitas air akuarium pemeliharaan yang meliputi, suhu, $\mathrm{pH}$, salinitas, DO, amonia selama penelitian.

\section{HASIL DAN PEMBAHASAN Total Hemosit}

Hasil pengamatan terhadap total hemosit udang vaname (Litopenaeus vannamei) yang dilakukan pada hari ke-0 yaitu pada awal penelitian, hari ke-14 sebelum udang diinfeksi dengan bakteri Vibrio harveyi, pada hari ke-16 (1 hari pasca infeksi) dan pada hari ke-26 (10 hari pasca infeksi) dapat dilihat pada Tabel 1. 
Tabel 1. Nilai rata-rata total hemosit selama penelitian

\begin{tabular}{|c|c|c|c|c|}
\hline \multirow{2}{*}{ Perlakuan } & \multicolumn{4}{|c|}{ THC $\left(\times 10^{6}\right.$ sel/ml \pm SD } \\
\cline { 2 - 5 } & Hari ke-0 & Hari ke-14 & Hari ke-16 & Hari ke-26 \\
\hline A (+) & $20,27 \pm 1,80^{\mathrm{a}}$ & $21,75 \pm 1,54^{\mathrm{a}}$ & $10,86 \pm 0,63^{\mathrm{a}}$ & $11,80 \pm 5,90^{\mathrm{a}}$ \\
\hline A (-) & $21,10 \pm 1,76^{\mathrm{a}}$ & $22,71 \pm 1,82^{\mathrm{a}}$ & $23,16 \pm 1,16^{\mathrm{d}}$ & $23,15 \pm 1,11^{\mathrm{b}}$ \\
\hline B & $20,80 \pm 0,35^{\mathrm{a}}$ & $23,90 \pm 2,18^{\mathrm{a}}$ & $16,42 \pm 1,20^{\mathrm{b}}$ & $19,26 \pm 9,70^{\mathrm{b}}$ \\
\hline C & $21,60 \pm 2,33^{\mathrm{a}}$ & $24,30 \pm 3,62^{\mathrm{a}}$ & $17,90 \pm 2,00^{\mathrm{b}}$ & $20,27 \pm 0,95^{\mathrm{b}}$ \\
\hline D & $21,87 \pm 0,81^{\mathrm{a}}$ & $24,50 \pm 1,88^{\mathrm{a}}$ & $20,57 \pm 2,62^{\mathrm{c}}$ & $22,17 \pm 2,43^{\mathrm{b}}$ \\
\hline E & $20,80 \pm 2,82^{\mathrm{a}}$ & $28,34 \pm 1,72^{\mathrm{b}}$ & $20,83 \pm 0,81^{\mathrm{cd}}$ & $22,76 \pm 1,00^{\mathrm{b}}$ \\
\hline
\end{tabular}

Keterangan :

$\mathrm{A}+=$ Ekstrak air panas Spirulina platensis $0 \mathrm{mg} / \mathrm{kg}$

A- = Ekstrak air panas Spirulina platensis $0 \mathrm{mg} / \mathrm{kg}$

$\mathrm{B}=$ Ekstrak air panas Spirulina platensis $200 \mathrm{mg} / \mathrm{kg}$

C = Ekstrak air panas Spirulina platensis $400 \mathrm{mg} / \mathrm{kg}$

$\mathrm{D}=$ Ekstrak air panas Spirulina platensis $600 \mathrm{mg} / \mathrm{kg}$

$\mathrm{E}=$ Ekstrak air panas Spirulina platensis $800 \mathrm{mg} / \mathrm{kg}$

Subscript yang berbeda pada kolom yang sama menunjukkan hasil yang berbeda nyata $(\mathrm{P}<0,05)$

\section{Kelangsungan Hidup (Survival Rate)}

Hasil pengamatan terhadap kelangsungan hidup udang vaname (Litopenaeus vannamei) dilakukan dengan cara mengamati perubahan tingkah laku udang pasca diinjeksi dengan bakteri Vibrio harveyi kemudian dihitung jumlah kematian udang selama 10 hari untuk mengetahui respon imun terhadap kelangsungan hidup udang dapat dilihat pada Tabel 2.

Tabel 2.Nilai rata-rata kelangsungan hidup udang vaname (Litopenaeus vannamei) pasca infeksi Vibrio harveyi.

\begin{tabular}{|c|c|}
\hline Perlakuan & SR (Survival Rate) \\
\hline A + & $5 \pm 10,00^{\mathrm{a}}$ \\
\hline A- & $62,5 \pm 9,57^{\mathrm{c}}$ \\
\hline B & $22,5 \pm 17,07^{\mathrm{ab}}$ \\
\hline $\mathrm{C}$ & $32,5 \pm 21,60^{\mathrm{ab}}$ \\
\hline $\mathrm{D}$ & $40 \pm 21,60^{\mathrm{bc}}$ \\
\hline $\mathrm{E}$ & $57,5 \pm 12,58^{\mathrm{c}}$ \\
\hline
\end{tabular}

Keterangan :

A+ = Tanpa ekstrak air panas Spirulina platensis dan diinjeksi Vibrio harveyi

A- = Tanpa ekstrak air panas Spirulina platensis dan diinjeksi PBS

$\mathrm{B}=$ Ekstrak air panas Spirulina platensis $200 \mathrm{mg} / \mathrm{kg}$ pakan dan diinjeksi Vibrio harveyi

$\mathrm{C}=$ Ekstrak air panas Spirulina platensis $400 \mathrm{mg} / \mathrm{kg}$ pakan dan diinjeksi Vibrio harveyi

D = Ekstrak air panas Spirulina platensis $600 \mathrm{mg} / \mathrm{kg}$ pakan dan diinjeksi Vibrio harveyi

$\mathrm{E}=$ Ekstrak air panas Spirulina platensis $800 \mathrm{mg} / \mathrm{kg}$ pakan dan diinjeksiVibrio harveyi

Subscript yang berbeda pada kolom yang sama menunjukkan hasil yang berbeda nyata $(\mathrm{P}<0,05)$

\section{Pembahasan}

Berdasarkan hasil perhitungan statistik pada Tabel 1 diketahui bahwa jumlah total hemosit menunjukkan hasil yang berfluktuasi. Menurut Jusilla (1997) dalam Putri dkk. (2013) jumlah hemosit yang berfluktuasi dalam hemolim krustasea menunjukkan reaksi yang berbeda terhadap stressor lingkungan dan penyakit, sehingga dapat menjadi indikator status kesehatan krustasea dan adanya stressor lingkungan. 
Pada hari ke-0 jumlah total hemosit udang vaname berkisar antara 20,27 $\times 10^{6}-21,87 \times 10^{6} \mathrm{sel} / \mathrm{ml}$. Pada hari ke-14 nilai total hemosit ini meningkat menjadi $21,75 \times 10^{6}-26,92 \times 10^{6} \mathrm{sel} / \mathrm{ml}$ dengan jumlah total hemosit tertinggi terlihat pada perlakuan E yaitu sebesar 26,92 x $10^{6} \mathrm{sel} / \mathrm{ml}$. Pada hari ke-16 hemosit mengalami penurunan dengan nilai rata-rata sekitar 10,75 $\times 10^{6}-23,16 \times 10^{6} \mathrm{sel} / \mathrm{ml}$. Penurunan ini diakibatkan pada hari ke-15 udang diuji tantang dengan diinjeksi menggunakan bakteri Vibrio harveyi $10^{6} \mathrm{sel} / \mathrm{ml}$. Menurut Van de Braak et al. (2002) penurunan total hemosit setelah uji tantang berhubungan dengan aktivitas pertahanan berbeda yang menyebabkan berkurangnya konsentrasi sel hemosit dalam hemolim.

Pada hari ke 26 hemosit kembali mengalami kenaikan jumlah dibandingkan dengan jumlah total hemosit pada pada hari ke 16 yaitu dengan kisaran nilai ratarata $11,8 \times 10^{6}-23,15 \times 10^{6} \mathrm{sel} / \mathrm{ml}$. Hal ini sesuai dengan hasil penelitian yang dilakukan oleh Pebrianto dkk. (2010) yang menyatakan bahwa peningkatan total hemosit setelah perlakuan ini menunjukkan adanya kemampuan bahan aktif dari ekstrak untuk meningkatkan imunitas dengan cepat. Peningkatan ini diduga merupakan respon dari sistem kekebalan tubuh pada udang oleh hemosit.

Uji statistik terhadap kelangsungan hidup dari udang vaname (Litopenaeus vannamei) menunjukkan bahwa terdapat perbedaan yang nyata $(\mathrm{p}<0,05)$ terhadap nilai kelangsungan hidup semua perlakuan. Nilai kelangsungan hidup tertinggi terdapat pada perlakuan A- (kontrol negatif) yaitu perlakuan tanpa pemberian ekstrak air panas Spirulina platensis dan diinjeksi dengan larutan PBS (Phosphat Buffer Saline) sebesar $62,5 \%$. Nilai kelangsungan hidup terendah terdapat pada perlakuan $\mathrm{A}+$ (kontrol positif) yaitu perlakuan tanpa pemberian ekstrak Spirulina platensis dan udang diinjeksi dengan bakteri Vibrio harveyi sebesar $5 \%$. Sedangkan untuk perlakuan dengan penambahan ekstrak air panas Spirulina platensis diketahui nilai kelangsungan hidup atau SR (Survival Rate) tertinggi terdapat pada perlakuan $\mathrm{E}$ $(57,5 \%)$ yaitu perlakuan dengan penambahan ekstrak air panas Spirulina platensis pada pakan dengan dosis sebesar 800 $\mathrm{mg} / \mathrm{kg}$ pakan. Pada perlakuan D (penambahan $600 \mathrm{mg}$ ekstrak/kg pakan) kelangsungan hidupnya sebesar $40 \%$, perlakuan C (penambahan 400mg ekstrak/kg pakan) $32,5 \%$, perlakuan B (penambahan $200 \mathrm{mg}$ ekstrak/kg pakan) $22,5 \%$.

Nilai kelulushidupan atau SR (Survival Rate) yang tinggi tidak lepas dari peran sistem imun dalam tubuh udang. Menurut Kozlenko and Henson (2006) Spirulina adalah sumber bahan alami yang dikenal mampu meningkatkan sistem imun.Penelitian terhadap Spirulina sebagai pakan dalam jumlah sedikit sudah cukup berpengaruh terhadap peningkatan sistem imun.Molekul imun ini banyak ditemukan di hemosit dalam hemolim udang dimana reaksi imun terjadi (Tassanakajon et al., 2014).

Pemeriksaan kadar garam perairan menunjukkan kondisi salinitas yang stabil yaitu antara 30-32 ppt. Konsentrasi oksigen terlarut atau DO selama penelitian berkisar antara 6,3-8,2. Hasil pengukuran $\mathrm{pH}$ selama penelitian berkisar antara 7,17-8,29. Suhu air selama penelitian pada pagi hari berkisar antara $26,1^{\circ}-31,7^{\circ} \mathrm{C}$. Kandungan ammonia selama penelitian berkisar antara 0,25-0,5 mg/l. Secara keseluruhan kualitas media air pemeliharaan udang vaname dalam penelitian ini berada dalam kondisi yang optimum untuk pemeliharaan udang sehingga dapat disimpulkan bahwa kematian terhadap udang vaname terjadi berasal dari perlakuan yang diberikan selama penelitian.

\section{KESIMPULAN DAN SARAN Kesimpulan}

Penambahan ekstrak air panas Spirulina platensis pada pakan terbukti berpengaruh dan mampu meningkatkan jumlah total hemosit dan nilai presentase kelulushidupan (Survival Rate) udang 
vaname (Litopenaeus vannamei) pasca infeksi dengan bakteri Vibrio harveyi.

\section{Saran}

Perlu dilakukan penelitian lanjutan apakah pemberian ekstrak air panas Spirulina platensis juga memiliki pengaruh terhadap sistem pertahanan tubuh pada ikan atau udang spesies lain yang diuji tantang dengan bakteri atau parasit lain sehingga penggunaannya dapat diaplikasikan dalam ruang lingkup yang lebih luas.

\section{DAFTAR PUSTAKA}

Balai Budidaya Air Payau Jepara. 2012. Petunjuk Teknis Pembenihan Udang Vaname. Kementrian Kelautan dan Perikanan Direktorat Jenderal Perikanan Budidaya. Situbondo. Jawa Timur. 23 hal.

Belay, A. 2002. The Potential Application of Spirulina (Arthrospira) as a Nutritional and Therapeutic Supplement in Health Management. The Journal of the American Nutraceutical Association 5 (2).27-40 p.

Evan, Y. 2009. Uji Ketahanan Beberapa Strain Larva Udang Galah (Macrobrachium rosenbergii de Man) Terhadap Bakteri Vibrio harveyi. Teknologi dan Manajemen Perikanan Budidaya Departemen Budidaya Perairan Fakultas Perikanan dan Ilmu Kelautan. Institut Pertanian Bogor.51 hal.

Hashem, M. and M.E. Barbary. 2013. Vibrio harveyi Infection in Arabian Surgeon Fish (Achanturus sohal) of Red Sea at Hurghada, Egypt. National Institute of Oceanogaphy and Fisheries.Egyptian Journal of Aquatic Research vol 39.199-203 p.

Hayashi, O., Ono, S., Ishii, K., Shi, Y.H., Hirahashi, T., and T. Katoh. 2006. Enhancement of Profeliration and Differentation in Bone Marrow Hematopoetic Cells by Spirulina (Arthospira) platensis in Mice. Journal of Apllied Technology.18 p.

Huang, H.H., Liu, X.L., Xiang, J.H and P. Wang. 2013. Immune response of Litopenaeus vannamei after infection with Vibrio harveyi. 5 p.

Ibrahem, M.D and M.A. Ibrahim. 2014. The Potential Effects of Spirulina platensis (Arthrospira platensis) on Tissue Protection of Nile Tilapia (Oreochromis niloticus) Through Estimationof P53 level. Faculty of Veterinary Medicine. Cairo University.133-136 p.

Pebrianto, C.A., Sukenda., dan Widanarni. 2010. Potensi Trichoderma sp. Sebagai Bahan Antibakterial dan Imunostimulan pada Udang Vaname (Litopenaeus vannamei). Departemen Budidaya Perairan, Fakultas Perikanan dan Ilmu Kelautan, Institut Pertanian Bogor, Bogor. 1-8 hal.

Putri, F. M., Sarjito dan Suminto. 2013. Pengaruh Penambahan Spirulina sp. dalam Pakan Buatan terhadap Jumlah Total Hemosit dan Aktivitas Fagositosis Udang Vaname (Litopeaneus vanamei). Journal of Aquaculture Management and Technology 2 (1). 102-112 hal.

Ridlo, A., dan R. Pramesti. 2009. Aplikasi Ekstrak Rumput Laut Sebagai Agen Imunostimulan Sistem Pertahanan Non Spesifik Pada Udang (Litopenaeus vannamei). Jurusan Ilmu Kelautan. Fakultas Perikanan dan Kelautan Universitas Diponegoro. Semarang. 5 hal.

Syahilatua, D.Y. 2009. Seleksi Bakteri Probiotik Sebagai Stimulator Sistem Imun pada Udang Vaname. Sekolah Pasca Sarjana. Institut Pertanian Bogor. Bogor. 58 hal.

Tampangallo, B.R., Pakidi, C.S., dan A Rantentondok. 2012. Respon Udang Windu (Penaeus monodon) yang Dipapar Bakteri Vibrio harveyi. Prosiding Insinas.5 hal. 
Tayag, C.M. Lin. Y.C., Li. C.C., Liou. C.H., and J.C. Chen. 2010. Administration of the Hot-water Extract of Spirulina platensis Enhanced the Immune Response of White Shrimp Litopenaeus vannamei and its Resistance Against Vibrio alginolyticus. 8 p.

Van de Braak, C.B.T., Botterblom, M.H.A., Liu, W., Taverne, N., Van der Knaap, M. T.W., and J.W.H. Rombout. 2002. The Role of the Haematopoietic Tissue in Haemocyte Production and Maturation in the Black Tiger Shrimp (Penaeus monodon). $20 \mathrm{p}$.

Widagdo, P. 2011. Aplikasi, Probiotik, Prebiotik dan Sinbiotik Melalui Pakan Pada Udang Vaname Litopenaeus vannamei yang Diinfeksi Bakteri Vibrio Harveyi. Departemen Budidaya Perairan. Fakultas Perikanan dan Ilmu Kelautan. Institut Pertanian Bogor. Jawa Barat. 42 hal. 